\title{
Gambogic Acid as a Candidate for Cancer Therapy: A Review
}

This article was published in the following Dove Press journal:

International Journal of Nanomedicine

\author{
Yuling Liu' \\ Yingchong Chen ${ }^{2}$ \\ Longfei Lin' \\ Hui Li \\ 'Institute of Chinese Materia Medica, \\ China Academy of Chinese Medical \\ Sciences, Beijing, People's Republic of \\ China; ${ }^{2}$ Key Laboratory of Modern \\ Preparation of TCM, Ministry of \\ Education, Jiangxi University of \\ Traditional Chinese Medicine, Nanchang, \\ People's Republic of China
}

\begin{abstract}
Gambogic acid (GA), a kind of dry resin secreted by the Garcinia hanburyi tree, is a natural active ingredient with various biological activities, such as anti-cancer, antiinflammatory, antioxidant, anti-bacterial effects, etc. An increasing amount of evidence indicates that GA has obvious anti-cancer effects via various molecular mechanisms, including the induction of apoptosis, autophagy, cell cycle arrest and the inhibition of invasion, metastasis, angiogenesis. In order to improve the efficacy in cancer treatment, nanometer drug delivery systems have been employed to load GA and form micelles, nanoparticles, nanofibers, and so on. In this review, we aim to offer a summary of chemical structure and properties, anti-cancer activities, drug delivery systems and combination therapy of GA, which might provide a reference to promote the development and clinical application of GA. Keywords: gambogic acid, anti-cancer activities, drug delivery systems, combination therapy
\end{abstract}

\section{Introduction}

Cancer has a highly growing incidence and mortality, which is a major public health problem worldwide. GLOBOCAN 2018 estimated 18.1 million new cases and 9.6 million cancer deaths in 2018 by investigating 36 cancers in 185 countries. ${ }^{1}$ Chemotherapy is a type of malignant cancer treatment that extensively uses drugs to kill cancer cells. Herbal medicines are gifts from nature, exhibiting broad spectrum therapeutic potentials for a long time, especially in the field of anti-cancer activity. Plenty of active ingredients exist in the plants and have the great potential to develop into therapeutic drugs for cancer therapy, prolonging survival time, reducing side effects and improving the quality of life for cancer patients. ${ }^{2}$ Drugs containing the xanthone structure have had a lot of attention due to the potential in inhibiting tumor growth. Xanthone compounds, as one kind of natural product, were originally isolated from plants and microorganisms, which have anti-tumor, anti-hypertensive, anti-thrombotic and other biological activities. ${ }^{3}$

Gambogic acid (GA), a naturally occurring prenylated xanthone moiety, is the most important member of the xanthone family that is investigated for its pharmaceutical consequentiality. ${ }^{4}$ GA, secreted as a dry resin by the Garcinia hanburyi tree, possesses several anticancer activities that have been documented, such as apoptosis, autophagy, cell cycle arrest and the inhibition of invasion, metastasis, and angiogenesis (Figure 1). GA could inhibit various cancer cell's growth, including breast cancer, pancreatic cancer, prostate cancer, lung cancer, osteosarcoma, etc., which might be related with modulating the signaling pathways of c-Jun
Institute of Chinese Materia Medica,

China Academy of Chinese Medical

Sciences, 16 Nanxiao Street,

Dongzhimen, Dongcheng District, Beijing,

People's Republic of China

Email lihuizys@I26.com
International Journal of Nanomedicine 2020:I5 10385-10399

10385

DovePress if in $b$

http://doi.org/10.2147/IJN.S277645 


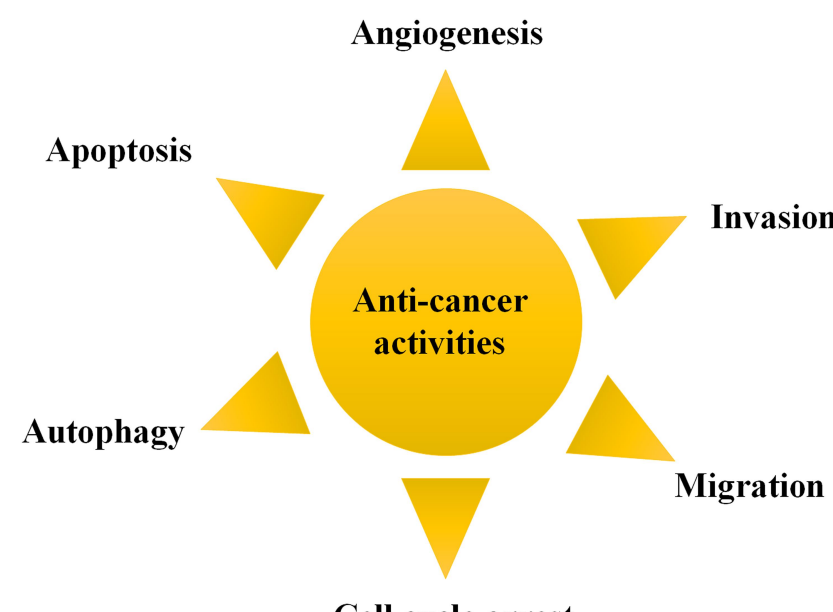

Cell cycle arrest

Figure I Anti-cancer activities of GA.

N-terminal kinase-1 (JNK-1), protein kinase B (AKT)/ mammalian target of rapamycin (mTOR), AKT/ forkhead box protein O1(FOXO1)/BIM, nuclear factor kappa-B $(\mathrm{NF}-\mathrm{kB})$ and so on. Although GA has been approved by the China Food and Drug Administration (CFDA) for Phase II clinical trials by intravenous injection in solid tumor therapy, ${ }^{5,6}$ there are still some problems needing to be solved for the purpose of accelerating the clinical applications. GA is mainly extracted from some plants but in low yield, and its complex chemical structure makes it difficult to synthesize. Moreover, the rigid structure and the poor water solubility of GA leads to the limitation of pharmacokinetic properties. ${ }^{7}$ Therefore, how to utilize the new technology to overcome the drawbacks of GA in order to enhance the applications is particularly important. The new drug delivery system based on nanotechnology could usefully encapsulate GA to overcome the poor water solubility and enhance the therapeutic effects in cancer therapy. This review aims to summarize the physical and chemical properties, structure-activity relationship, anticancer activities, the underlying molecular mechanisms, nano-drug delivery systems, as well as combination therapy of GA, to improve the developing speed of the preclinical study in the future.

\section{Chemical Structures and Properties of Gambogic Acid}

GA $\left(\mathrm{C}_{38} \mathrm{H}_{44} \mathrm{O}_{8}, \mathrm{MW}: 628.75\right.$, Figure 2), the major active component accompanyied by a caged polyprenylated xanthone derived from Garcinia hanburyi, is a kind of brownish-to-orange resin, which is mainly found in South China, Vietnam, Cambodia and Thailand. ${ }^{8}$ The boiling

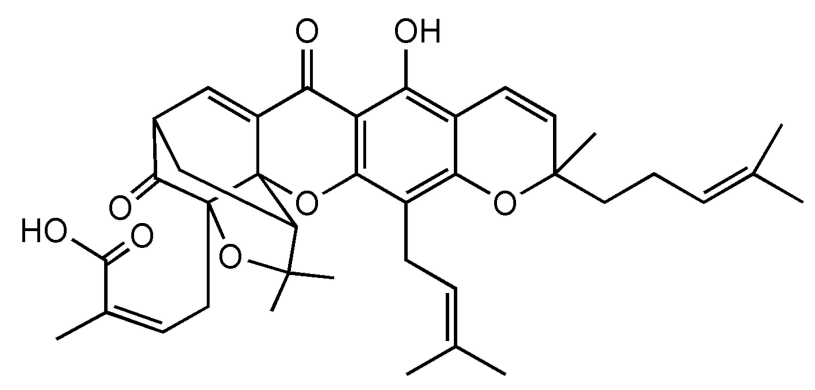

Figure 2 Structure of Gambogic acid.

point and flash point of GA is $808.9{ }^{\circ} \mathrm{C}$ and $251.4{ }^{\circ} \mathrm{C}$, respectively. GA also possesses a maximum absorption wavelength of $365 \mathrm{~nm}$ as well as the unique xanthone skeleton. ${ }^{2}$ The molecular structure of GA was elucidated in 1965 mainly via detailed nuclear magnetic resonance (NMR) analysis, and there were several synonyms, including guttic acid, guttatic acid, $\beta$-guttiferin,2-methyl4-[(1R,3aS,5S,11R,14aS)-3a,4,5,7tetrahydro-8-hydroxy-3, 3,11-trimethyl-13-(3-methyl-2buten-1-yl)-11-(4-methyl-3penten-1-yl)-7,15-dioxo-1,5-methano-1H,3H,11 H-furo [3, 4-g] pyrano [3,2-b] xanthen-1yl]-2Z-botanical acid, etc. ${ }^{2,9}$ The studies reported that GA had been used in traditional Chinese medicine for hundreds of years and possessed diverse biological effects including anti-inflammatory, antioxidant, anti-viral, and anti-infectiousness, especially in the field of anti-cancer in recent years. ${ }^{10,11}$ The overall yield of GA isolated from available gamboge resin was approximately $5 \%$. The method of purification was converting the crude gamboge resin extract into the pyridine salt, following the subsequent crystallization. ${ }^{12}$ Besides, it was reported that GA was found to be stable in acetone, acetonitrile, chloroform and other acids, but unstable in methanol. $^{5}$

Based on the activity relationship studies, the 9,10 carbon double bond of $\alpha, \beta$-unsaturated ketone moiety from GA plays an important role for its biological activity and various modifications can be performed in the 6-hydroxy and 3o-carboxy group. ${ }^{13}$ The electrophilic $\alpha, \beta$-unsaturated carbonyl group in the bioactive compounds could specifically react with protein thiols. In previous studies, GA could inhibit the activation of NF- $\mathrm{KB}$ via modifying the 179Cys of IKK $\beta$, resulting in an anti-inflammatory effect via the decrease of COX-2, TNF $\alpha$ and iNOS. ${ }^{14}$ Furthermore, GA could also suppress the activation of thioredoxin (TRX-1/2) proteins by covalently binding to the active cysteine residues via Micheal addition reactions. ${ }^{15}$ These explorations on the 
relationship between structure and activity of GA would provide a reference for the development of GA as a potent drug in clinics.

\section{Anti-Cancer Mechanisms}

\section{Apoptosis}

Figure 3 shows the anti-apoptotic pathway of GA in cancers. p53 is a crucial tumor suppressor gene mutated in most human cancers, which correlates with cell apoptosis, cell cycle arrest, metabolic adaptation and senescence. ${ }^{16}$ Both transcriptionindependent and transcription-dependent ways could target p53 to induce apoptosis, including inhibition of p53-MDM2 interaction, targeting p53 family protein, elimination of mutant $\mathrm{p} 53$, restoring mutated $\mathrm{p} 53$ and so on. ${ }^{17}$ Initially, GA was considered as an antagonist of bcl-2 family proteins in Hela cells. ${ }^{18}$ In human breast cancer cells (MCF-7), GA was found to inhibit bcl-2 expression by increased $\mathrm{p} 53$ resulting in cell apoptosis. ${ }^{19}$ Furthermore, GA increases p53 expression via down-regulating MDM2 in wild type p53 expressing human cancer cells (non-small cell lung H1299). ${ }^{20}$ Interestingly, GA could enhance $\mathrm{p} 21^{\mathrm{Waf} 1 / \mathrm{CIP} 1}$ expression to induce cell apoptosis in human breast cancer cells (MCF-7) via suppressing MDM2 with or without p53 activation. ${ }^{21}$ It's reported that MDM2 activation was not the underlying cause for the stability of mutant p53 in cancer. GA could enhance the degradation of mutant p53 in MDA-MB-435 cells (with p53 mutation) by chaperones-related (Hsp70 and Hsp90) ubiquitin/proteasome pathway. Hsp70 and Hsp90 could present mutant p53 to chaperone-associated ubiquitin ligase carboxy terminus of Hsp70-interacting protein (CHIP) to induce degradation by proteasome. GA promoted the interaction between mutant p53 and Hsp70, while inhibiting the formation of Hsp90/mutant p53 complex. ${ }^{22}$ Meanwhile, GA was considered as a natural product inhibitor of Hsp90. ${ }^{23,24}$ On the contrary, previous studies showed that GA functioned as an inhibitor of the ubiquitin-proteasome system (especially $20 \mathrm{~S}$ proteasome) to induce cytotoxicity in melanoma cells. ${ }^{25-27}$ The influence of GA on the ubiquitin-proteasome system needs further investigation.

Mitochondria-dependent apoptosis (intrinsic apoptosis pathway) mainly involves activated caspase-3 through bcl2 family members, while mitochondria-independent apoptosis (extrinsic apoptosis pathway) is related to death ligands and receptors. ${ }^{28}$ In mitochondria-dependent apoptosis pathway, bcl-2 reduction is associated with the release of cytochrome $\mathrm{c}$, leading to an apoptosis cascade reaction. ${ }^{29}$ GA could induce an intrinsic apoptosis pathway by directly targeting the mitochondria with a rapid mitochondrial membrane depolarization and fragmentation, causing the release of cytochrome c, activation of caspase-3, 9 and cleaved

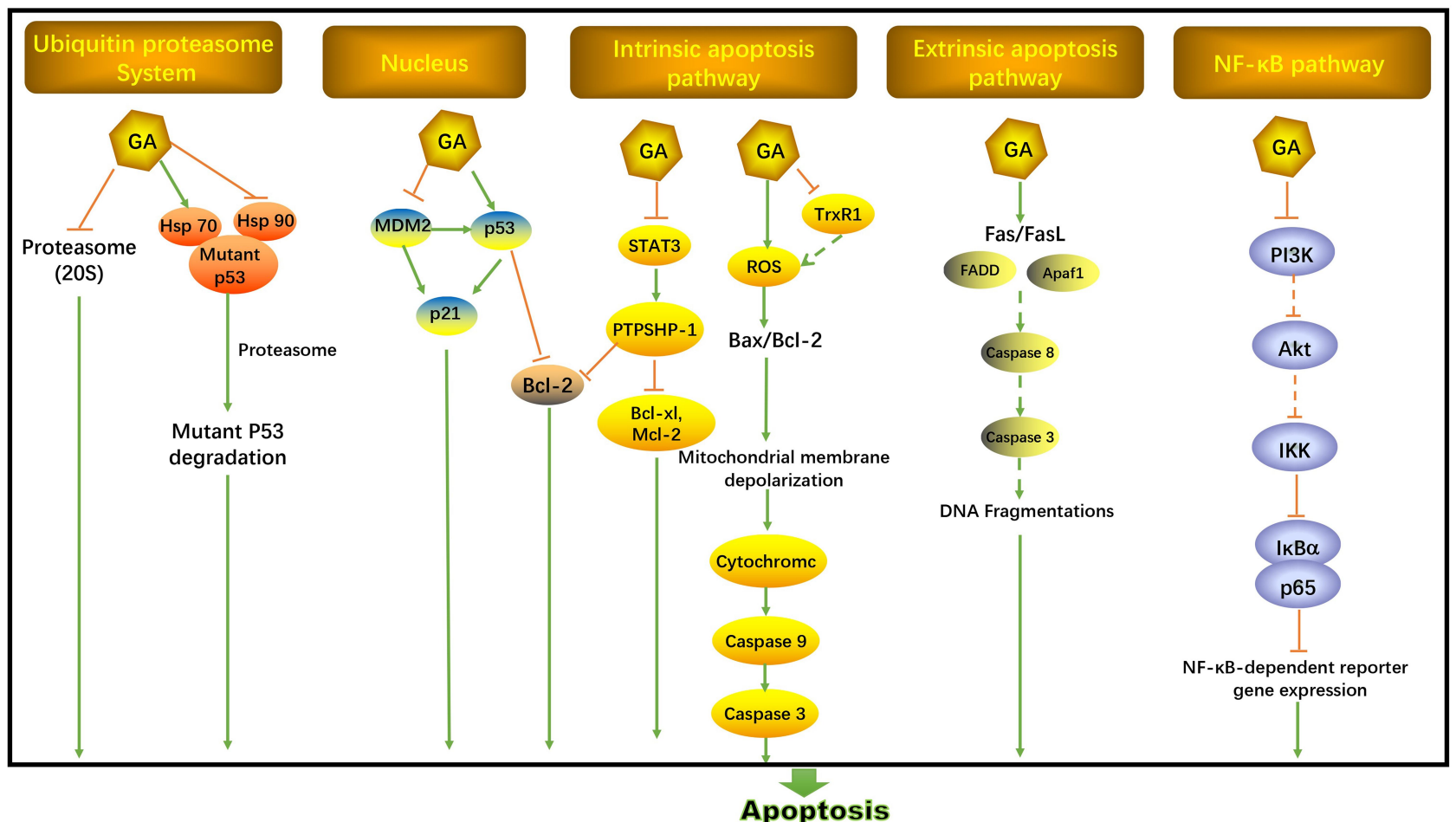

Figure 3 Anti-apoptosis activities of GA. 
PARP and increased ratio of bax/bcl-2. GA-induced reactive oxygen species (ROS) may be the cause of the collapse of mitochondrial transmembrane potential, which could also down-regulate SIRT1 in multiple myeloma and enhance the phosphorylation of c-Jun-N-terminal protein kinase (JNK) and p38 in hepatoma SMMC-7721 cells. ${ }^{30-38}$ GA may also interact with the thioredoxin reductase 1 (TrxR1) to elicit oxidative stress leading to ROS accumulation in hepatocellular carcinoma. ${ }^{39}$ Extrinsic apoptosis pathway was also induced by GA with increased death receptor (Fas, FasL, Fas-associated protein with death domain (FADD) and Apaf-1) and deoxyribonucleic acid (DNA) fragmentation. ${ }^{35,36,40}$ Interestingly, GA was found to bind to the transferrin receptor and might induce a special signal resulting in rapid apoptosis in cancer. ${ }^{40-42}$

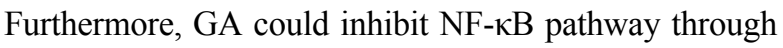
suppressing $\mathrm{I} \kappa \mathrm{B} \alpha$ and $\mathrm{p} 65$ phosphorylation resulting in abrogated NF- $\kappa B$-dependent reporter gene expression. ${ }^{24,42,43}$ AKT and PI3K may be also involved in GA-induced apoptosis relating to the NF- $\kappa$ B pathway. ${ }^{44,45}$ GA also suppressed the signal transducer and activator of transcription (STAT3) phosphorylation to induce cell apoptosis through activating protein tyrosine phosphatase SHP-1, which down-regulated the expression of STAT3-associated antiapoptotic proteins (bcl-xl, bcl-2 and Mcl-2) in myeloma cells. ${ }^{46}$ For prostate cancer with phosphate and tension homology (PTEN) and p53 genes deletion, GA induced cell apoptosis via suppression of mitogen-activated protein kinases (MAPK) pathway and c-fos. ${ }^{47}$ With the higher expression of miR-21 in multiple myeloma, GA induced cell apoptosis and proliferation through the regulation of the AKT/FOXO1/BIM signaling pathway. ${ }^{48}$ Notch signaling pathway was also involved in GA-induced apoptosis with reduction of bcl-2 and PI3K in non-small cell lung cancer. ${ }^{49}$

In addition, GA-associated targets in apoptosis have been found in various types of cancers, including TR3 in cervical cancer, ${ }^{50}$ hERG and steroid receptor coactivator-3 (SRC-3) in leukemia, ${ }^{51,52}$ BRD4 in anaplastic thyroid cancer, ${ }^{53}$ DDIT3, DUSP1, DUSP5, GADD45B, TOP2A, TOP2B, TOP3A and ALDOA in pancreatic cancer. ${ }^{8} \mathrm{GA}$ could also enhance epidermal growth factor receptor (EGFR) degradation and inhibit AKT/mTOR complex 1 (mTORC1) via up-regulating AMP-activated protein kinase (AMPK)-dependent-leucine-rich repeats and immunoglobulin-like domains 1 (LRIG1) in glioma cells. ${ }^{54}$ Surprisingly, GA was able to induce cell apoptosis by activating $\mathrm{T}$ lymphocyte in $\mathrm{H} 22$ transplanted mice. ${ }^{55}$

\section{Cell Cycle Arrest}

The cell cycle arrest is one of the anti-cancer mechanisms, which is associated with the cell cycle process and cellular growth after the GA treatment (Figure 4). Several related researches revealed that GA distinctly influenced different cell phases on diverse types of cancer cell lines. GA could obviously induce $\mathrm{G} 2 / \mathrm{M}$ or $\mathrm{G} 0 / \mathrm{G} 1$ arrest in various cancer cell lines, such as MCF-7 cells, K562 cells, U2OS cells, and so on. Among them, G2/M arrest was induced by GA via decreasing the levels of phospho-cdc2 (Thr 161) and cdc25B in MG63 cells. ${ }^{56}$ Besides, Chen et al demonstrated that G2/M arrest in MCF-7 cells was induced by GA depolymerization of microtubules. ${ }^{10}$ GA could induce the G0/G1 phase cell cycle arrest and apoptosis in human chronic myelogenous leukemia cell line K562 cells via downregulating the expression of SRC-3 and inhibiting the Akt pathway. ${ }^{11}$ Similarly, GA treatment induced the G0/G1 phase arrest in U2OS cells was associated with a decrease in phospho-GSgsK3- $\beta$ (Ser9) and the expression of cyclin D1. ${ }^{56}$

\section{Autophagy}

GA provoked autophagy in NCI-H441 cells by upregulating the Beclin 1 (initiation factor for autophagosome formation) and converting LC3 I to LC3 II (autophagosome marker). ${ }^{57}$ Similarly, GA induced an apparent autophagy association with the up-regulated expressions of Atg5, Beclin 1 and LC3-II in glioblastoma multiforme (GBM) cells. ${ }^{58}$ Besides, GA treatment in A549 cells induced autophagy through suppressing the Akt/mTOR signaling pathway with the remarkable reduction of the phosphorylation levels of Akt, mTOR, and S6. ${ }^{59}$ Foggetti et al demonstrated that GA may induce mutp53 degradation through autophagy mechanism in human breast cancer cell line MDAMB-231 and human colorectal adenoma cell line DLD1 carrying $\mathrm{p} 53-\mathrm{S} 241 \mathrm{~F}$ in expressing the $\mathrm{p} 53-\mathrm{R} 280 \mathrm{~K}$ and the p53-S241F proteins, respectively. ${ }^{60}$ The autophagy of GA against colorectal cancer was regulated by 5-LOXgenerated ROS accumulation, which might associate with the inhibition of Akt-mTOR pathways. ${ }^{61}$ In human bladder cancer cells T24 and UMUC3, GA triggered ROS mediated autophagy through activating the JNK pathway. ${ }^{62}$

\section{Migration and Invasion}

The wound healing assay was performed to validate the effect of GA on the HT-29 colorectal cancer cell, which indicated that GA inhibits migration via blocking miR-21 activity. ${ }^{63}$ Such researches revealed that GA suppressed 


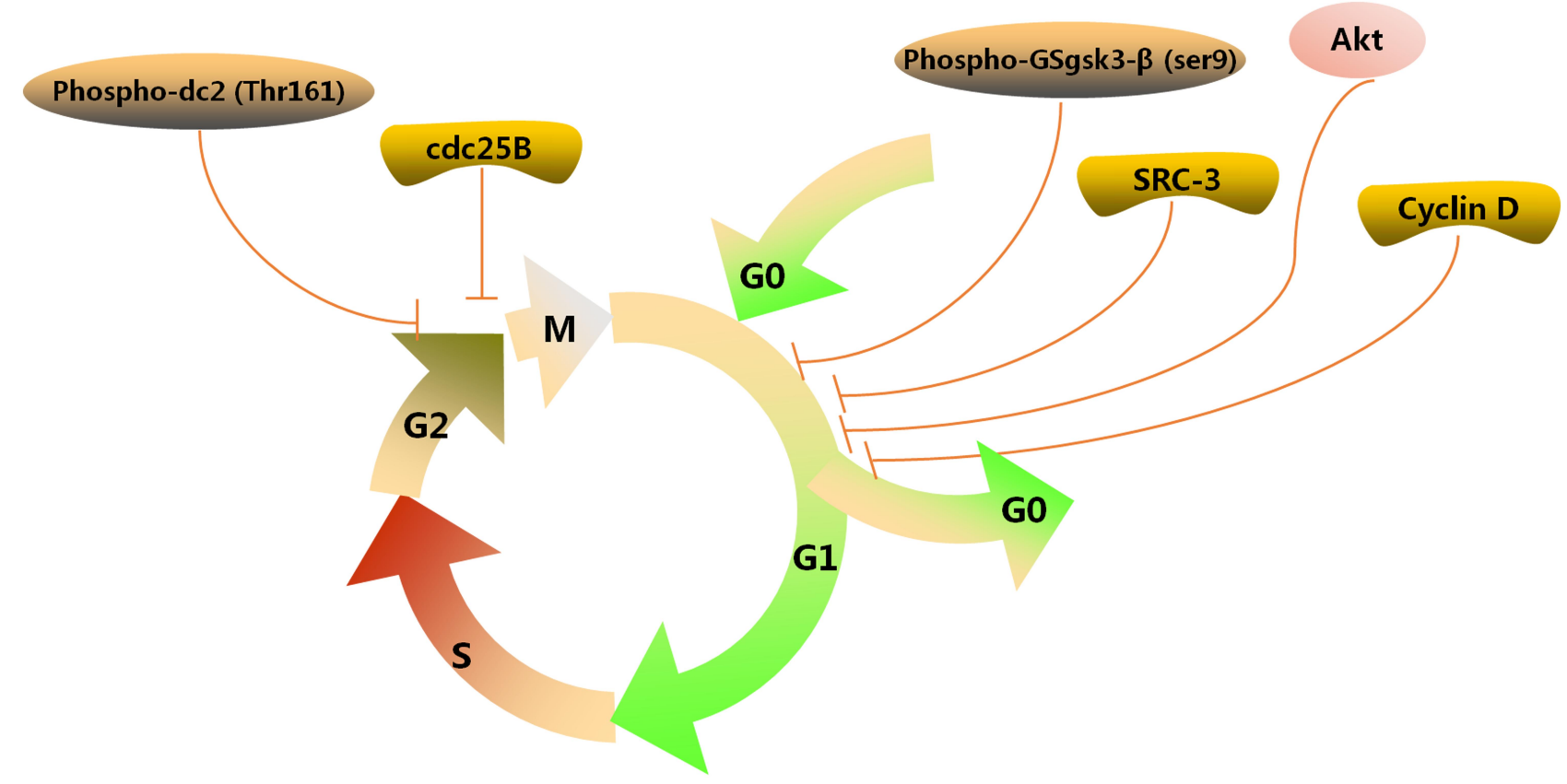

\section{Cell Cycle}

Figure 4 Cell cycle arrest mechanism of GA.

migration and invasion via activation of NF- $\mathrm{BB}$ pathway or the inhibition of matrix metalloproteinase (MMP)-2 and MMP-9 in A549 cells. $^{64,65}$ Moreover, GA also, dosedependently, suppressed MDA-MB-231 human breast carcinoma cell invasion and metastasis via the inhibition of MMP-2 and MMP-9. ${ }^{31,66,67}$ The migration and invasion of SK-HEP1 cells treated by GA were evaluated, the results showed that GA down-regulated the expression of the integrin $\beta 1 /$ rho family GTPase signaling pathway and suppressed the expression of MMP-2, MMP-9, and NF$\mathrm{Kb}{ }^{68} \mathrm{Lu}$ et al found that GA could inhibit TNF- $\alpha$-induced migration and invasion, likely mediated by regulation of the PI3K/Akt and NF- $\mathrm{KB}$ signaling pathways on human prostate cancer PC3 cells. ${ }^{69}$ The down-regulation of MMP-9 and the up-regulation of TIMP-1 played an important role in inhibiting the invasion of osteosarcoma cells treated by $\mathrm{GA}^{70}$ Besides, GA could inhibit the adhesion and migration in down-regulation of the $\alpha 4$ integrin expression on B16-F10 cells in vitro and in vivo. ${ }^{71}$

\section{Angiogenesis}

Angiogenesis plays an important role in tumor growth and has been a promising strategy for the treatment of cancer. ${ }^{72}$ Hypoxia-inducible factor- $1 \alpha$ (HIF-1 $\alpha$ ) plays a vital role in tumor progression. GA induced tumor antiangiogenesis via the inhibition of HIF-1 $\alpha$ VEGF in vivo, suggesting that GA may inhibit human multiple myeloma progression and angiogenesis. ${ }^{73}$ Other research also found that GA had the ability to inhibit angiogenesis correlated with inhibiting prolyl hydroxylase-2 (PHD2)-von Hippel-Lindau gene (VHL)-HIF-1 $\alpha$ pathway. ${ }^{74}$ Moreover, GA lead to the inhibition of angiogenesis by suppressing vascular endothelial growth factor receptor 2 (VEGFR 2) signaling. ${ }^{75}$

\section{Drug Resistance}

Drug resistance is a crucial obstacle in chemotherapy that may lead to treatment failure and relapse in patients with cancer. ${ }^{76}$ GA exhibits multi-target anti-cancer effects with few side effects, which shows the ability in reversing resistance to anti-cancer drugs in diverse cancer treatments. It was reported that GA could reverse oxaliplatin resistance in LoVo colorectal cancer cells through the approach of increasing intracellular platinum levels associated with the increase of hCTR1 levels and the decrease of ATP7A and ATP7B levels. ${ }^{77}$ Moreover, GA reduced the resistance to gemcitabine mainly through inhibiting the extracellular signal-regulated kinase (ERK)/E2F1 signaling pathway accompanied with the reduction of the ribonucleotide reductase subunit-M2 (RRM2) protein and mRNA 
expression. ${ }^{78}$ Hypoxia-inducible factor (HIF)-1 played an important role in inducing resistance to cancer therapy, however, Zhao et al showed evidence that GA reversed hypoxia-induced resistance to cisplatin-mediated apoptosis independently of HIF-1 $\alpha$ in osteosarcoma cells. ${ }^{79} \mathrm{GA}$ distinctly sensitized doxorubicin (DOX)-resistant breast cancer cells through inhibiting P-glycoprotein and suppressing the survivin expression revealed by ROS-mediated activation of the p38 MAPK. ${ }^{80} \mathrm{GA}$ also reversed docetaxel resistance through down-regulation of survivin in BGC-823/ Doc gastric cancer cell lines. ${ }^{81}$ Wang et al deemed that the combinational administration of gefitinib and GA had the ability to overcome gefitinib-resistant tumor growth caused by the EGFR T790M mutant lung cancer. ${ }^{82}$

\section{Nano-Scale Drug Delivery Systems}

To achieve higher anticancer efficiency, nano-scale drug delivery systems have been used to deliver anticancer drugs based on the enhanced permeation and retention (EPR) effect. $^{83}$ Different types of nano-scale drug delivery systems have been applied to modify or encapsulate GA, such as micelles, nanoparticles, nano-spheres, etc., which have been listed in Table 1. Furthermore, multifunctional nanoparticles have been investigated for $\mathrm{pH}$-sensitive, redoxsensitive, receptor targeting response, which may enhance drug release, improve drug accumulation in the tumor and reduce some side effects of GA. For example, hyaluronic acid (HA), folic acid (FA) and RGD are conjugated to the surfaces of the carriers for higher anticancer efficiency. ${ }^{84,85}$

\section{Micelles}

Self-assembled polymeric micelles have received growing attention in the field of drug delivery systems in recent years owing to the ability of drug solubilization, sustained drug release and drug targeting. ${ }^{86}$ Polymeric micelles consist of amphiphilic block copolymers, having a hydrophilic shell and a hydrophobic core, which can be used as a promising drug delivery system for the hydrophobic drugs. ${ }^{87}$ Table 1 has listed the micelles encapsulated with GA.

Mixed micelles self-assembled from two or more dissimilar block copolymers provide a direct and convenient approach to increase micelle stability and drug-loading efficiency, superior to those of the individual components. ${ }^{88} \mathrm{GA}$ was encapsulated in the mixed micelles constituted of Poloxamer 407 and TPGS, which showed increased cellular uptake and in vitro cytotoxicity compared with free GA in MCF-7 breast cancer cells and in multidrug resistant NCI/ ADR-RES cells. ${ }^{89} \mathrm{~N}$-octyl-N-arginine-chitosan micelles for
GA delivery might be the better target approach for getting less peripheral toxicity and higher targeting in liver and lung, which might be a promising formulation for GA to cure hepatic carcinoma or lung cancer in the future. ${ }^{90}$ The GAloaded mixed micelles made of poly(ethylene glycol)-poly (L-histidine)-poly(D,L-lactide-co-glycolide) (PEG-pHisPLGA) and D-a-tocopheryl polyethylene glycol 1000 (TPGS) included several abilities of having $\mathrm{pH}$-sensitive behavior, inhibiting P-gp expression and down-regulating of anti-apoptotic proteins, which increased the cell cytotoxicity of GA on both MCF-7 and MCF-7/ADR cells. ${ }^{91}$ Monomethylpoly(ethylene glycol)-poly(e-caprolactone)-poly (trimethylene carbonate) (MPEG-P(CL-ran-TMC)) was used to encapsulate GA, which showed superior antitumor efficacy and a better apoptosis induced effect in AsPC-1 cells compared to free GA. ${ }^{92} \mathrm{~N}$-octyl-N-arginine-chitosan (OACS) micelles prepared by the dialysis method were utilized for GA oral delivery, which increased solubility by 2320 times and several folds of absorption compared with GA. ${ }^{93}$

Besides, GA was encapsulated into the novel redox/pH dual-responsive and HA-decorated multifunctional magnetic complex micelles possessing excellent bioavailability, controllable release and multi-functionality, which could be an effective and promising strategy for the treatment of triple negative breast cancer. ${ }^{94} \mathrm{Ke}$ et al applied lecithin/solutol HS15 via the film-dispersion method to prepare the multilayer micelle employing protamine (PRM) and HA to deliver GA (HA-PRM-GA-M) for cancer treatment of inhibiting drug resistance. The results suggested that HA-PRM-GA-M showed the significant antitumor efficacy and tumor growth inhibitory effects without obvious histological abnormalities or hematological toxicity in the liver and kidney. ${ }^{95}$ Low molecular weight heparin (LMWH) with the function of antiangiogenesis effects showed favorable hydrophilicity and few side effects, which was grafted with GA to form the micelles in aqueous solution. This simultaneous combination of anti-angiogenesis drugs and chemotherapeutics achieved the aim of improving the anticancer efficacy by tumor-targeted delivery against hepatocellular carcinoma. ${ }^{96}$ Triphenylphosphonium (TPP), a mitochondriotropic molecule, was designed to target mitochondria by the reason of penetrating the mitochondrial intermembrane potential barrier. TPP was conjugated to micelles for delivering GA to overcome the shortages of GA and target the mitochondria, reaching the target of pro-apoptotic effect of lung cancer via mitochondrial signaling pathway with promoting the activities of caspase 3/7 and 9 as well as inducing the loss of MMP and the release of cytochrome c. ${ }^{97}$ 
Table I Drug Delivery Systems of GA

\begin{tabular}{|c|c|c|c|c|c|c|}
\hline $\begin{array}{l}\text { Delivery } \\
\text { Systems }\end{array}$ & Abbrev & Status & Functional Moiety & $\begin{array}{l}\text { Types of } \\
\text { Cancer }\end{array}$ & Cancer Cells & References \\
\hline \multirow[t]{11}{*}{ Micelles } & GA-OACS micelles & $\begin{array}{l}\text { In vitro and } \\
\text { in vivo }\end{array}$ & & $\begin{array}{l}\text { Hepatic } \\
\text { carcinoma }\end{array}$ & HepG2 cells & [90] \\
\hline & $\begin{array}{l}\text { GA encapsulated MPEG-P } \\
\text { (CLran-TMC) micelles }\end{array}$ & $\begin{array}{l}\text { In vitro and } \\
\text { in vivo }\end{array}$ & & $\begin{array}{l}\text { Pancreatic } \\
\text { cancer }\end{array}$ & AsPC-I cells & [92] \\
\hline & $\begin{array}{l}\text { sPEG/HA/CSO-SS-Hex } \\
\text { /Fe3O4/GA micelles }\end{array}$ & $\begin{array}{l}\text { In vitro and } \\
\text { in vivo }\end{array}$ & $\begin{array}{l}\text { CD44-target moiety: HA; redox- } \\
\text { responsive moiety: disulfide } \\
\text { linker; magnetic target moiety: } \\
\mathrm{Fe} 3 \mathrm{O} 4\end{array}$ & Breast cancer & $4 \mathrm{TI}$ cells & [94] \\
\hline & HA-GA@Ce6 micelles & $\begin{array}{l}\text { In vitro and } \\
\text { in vivo }\end{array}$ & $\begin{array}{l}\text { CD44-target moiety: HA; ROS } \\
\text { responsive moiety: } \mathrm{Ce} 6\end{array}$ & Breast cancer & $4 \mathrm{TI}$ cells & [99] \\
\hline & HA-PRM-GA-M & $\begin{array}{l}\text { In vitro and } \\
\text { in vivo }\end{array}$ & CD44-target moiety: HA & $\begin{array}{l}\text { Lung } \\
\text { adenocarcinoma }\end{array}$ & A549 cells & [95] \\
\hline & $\begin{array}{l}\text { PAG/DTX-shRNA } \\
\text { micelles }\end{array}$ & $\begin{array}{l}\text { In vitro and } \\
\text { in vivo }\end{array}$ & & Breast cancer & MCF-7 cells & {$[121]$} \\
\hline & GA-LMWH micelles & In vivo & & Hepatic cancer & $\mathrm{H}_{22}$ cells & [96] \\
\hline & GA-PEG-PCL micelles & In vitro & & Lung cancer & A549 cells & [97] \\
\hline & $\begin{array}{l}\text { PEG-pHis-PLGA/TPGS } \\
\text { micelles }\end{array}$ & In vitro & $\begin{array}{l}\text { pH sensitive moiety: poly } \\
\text { (L-histidine) (pHis) }\end{array}$ & Breast cancer & $\begin{array}{l}\text { MCF-7 cells; MCF-7/Adr } \\
\text { cells }\end{array}$ & {$[91]$} \\
\hline & $\begin{array}{l}\text { GA-PEG }{ }^{5 k} C_{4}-L_{-V} E_{4} \\
\text { micelles }\end{array}$ & $\begin{array}{l}\text { In vitro and } \\
\text { in vivo }\end{array}$ & & Colon cancer & $\mathrm{HT}-29$ and $\mathrm{HCTI} 16$ & [122] \\
\hline & $\begin{array}{l}\text { Poloxamer 407/TPGS } \\
\text { mixed micelles }\end{array}$ & In vitro & & Breast cancer & $\begin{array}{l}\text { MCF-7 cells; } \\
\text { NCI/ADR-RES cells }\end{array}$ & [89] \\
\hline \multirow[t]{9}{*}{ Nanoparticles } & GA-Cy7-NP & $\begin{array}{l}\text { In vitro and } \\
\text { in vivo }\end{array}$ & $\begin{array}{l}\text { Hypoxia target moiety: near- } \\
\text { infrared dye (Cy } 7)\end{array}$ & Prostate cancer & PC3 cells & {$[105]$} \\
\hline & iE-RBCm-GA/PLGA NPs & $\begin{array}{l}\text { In vitro and } \\
\text { in vivo }\end{array}$ & $\begin{array}{l}\text { EGFR-target moiety: bispecific } \\
\text { recombinant protein anti-EGFR- } \\
\text { iRGD }\end{array}$ & Colon cancer & $\begin{array}{l}\text { Caco- } 2 \text { cells; } \\
\text { SW480 cells }\end{array}$ & {$[106]$} \\
\hline & $\begin{array}{l}\text { GA and TRAIL co-loaded } \\
\text { BSA NPs }\end{array}$ & $\begin{array}{l}\text { In vitro and } \\
\text { in vivo }\end{array}$ & & $\begin{array}{l}\text { Breast cancer; } \\
\text { Lung cancer }\end{array}$ & MCF-7 cells;A549 cells & {$[123]$} \\
\hline & GA-loaded PEG-PCL NPs & $\begin{array}{l}\text { In vitro and } \\
\text { in vivo }\end{array}$ & & Gastric cancer & MKN-45 cells & {$[107]$} \\
\hline & CS/PLGA-GA NPs & $\begin{array}{l}\text { In vitro and } \\
\text { in vivo }\end{array}$ & & $\begin{array}{l}\text { Lewis lung } \\
\text { carcinoma }\end{array}$ & $\mathrm{LL} / 2$ cells & [124] \\
\hline & $\begin{array}{l}\text { LyP-I-LMWH-Qu (PLQ)/ } \\
\text { GA NPs }\end{array}$ & $\begin{array}{l}\text { In vitro and } \\
\text { in vivo }\end{array}$ & P32 target moiety: LyP-I & Breast cancer & MCF-7 cells & {$[125]$} \\
\hline & RBCm-GA/PLGA NPs & $\begin{array}{l}\text { In vitro and } \\
\text { in vivo }\end{array}$ & & $\begin{array}{l}\text { Colorectal } \\
\text { cancer; Gastric } \\
\text { cancer }\end{array}$ & $\begin{array}{l}\text { sW480 cells; MKN45 } \\
\text { cells; AGS cells }\end{array}$ & [108] \\
\hline & GA-HAS NPs & in vivo & & Lung cancer & A549 cells & [112] \\
\hline & GA/PTRAIL-HA/PPNPs & $\begin{array}{l}\text { In vitro and } \\
\text { in vivo }\end{array}$ & CD44-target moiety: HA & Breast cancer & $\begin{array}{l}\text { MCF-7 cells; MDA-MB } \\
-231 \text { cells }\end{array}$ & [109] \\
\hline
\end{tabular}


Table I (Continued).

\begin{tabular}{|c|c|c|c|c|c|c|}
\hline $\begin{array}{l}\text { Delivery } \\
\text { Systems }\end{array}$ & Abbrev & Status & Functional Moiety & $\begin{array}{l}\text { Types of } \\
\text { Cancer }\end{array}$ & Cancer Cells & References \\
\hline & $\begin{array}{l}\text { GA-loaded FA-Arg-PEUU } \\
\text { NPs }\end{array}$ & In vitro & $\begin{array}{l}\text { Folate receptor- target moiety: } \\
\text { folic acid (FA) }\end{array}$ & Lung cancer & $\begin{array}{l}\text { A549 cells; } \\
\text { Hela cells }\end{array}$ & {$[110]$} \\
\hline & DTX/GA PLGA NPs & $\begin{array}{l}\text { In vitro and } \\
\text { in vivo }\end{array}$ & & Breast cancer & $\begin{array}{l}\text { MCF-7 cells; MCF-7/Adr } \\
\text { cells }\end{array}$ & [126] \\
\hline & GA/RACC loaded NPs & In vitro & & $\begin{array}{l}\text { Osteosarcoma } \\
\text { cancer }\end{array}$ & MG63 cells & [127] \\
\hline & cRHG NPs & $\begin{array}{l}\text { In vitro and } \\
\text { in vivo }\end{array}$ & $\begin{array}{l}\alpha v \beta 3 \text { integrin target moiety: } \\
\text { cyclic arginine-glycine-asparagine- } \\
\text { tyrosine-lysine (c(RGDyK)) }\end{array}$ & $\begin{array}{l}\text { Breast cancer; } \\
\text { glioblastoma }\end{array}$ & $\begin{array}{l}\text { MCF-7 cells; } \\
\text { U87MG cells }\end{array}$ & [128] \\
\hline & GA-HRA NPs & $\begin{array}{l}\text { In vitro and } \\
\text { in vivo }\end{array}$ & & $\begin{array}{l}\text { Breast cancer; } \\
\text { nasopharyngeal } \\
\text { cancer }\end{array}$ & $\begin{array}{l}\text { MCF-7 cells; } \\
\text { KB3I cells }\end{array}$ & [129] \\
\hline & GA-MNP-Fe3O4 NPs & In vitro & & $\begin{array}{l}\text { Pancreatic } \\
\text { cancer; } \\
\text { leukemia }\end{array}$ & $\begin{array}{l}\text { Panc-I cells; Capan-I } \\
\text { cells; K562 cells }\end{array}$ & {$[101-103]$} \\
\hline Nano-spheres & F68-LA/GA nano-spheres & In vitro & & Ovarian cancer & A2780 cells & [113] \\
\hline Nanofibers & $\begin{array}{l}\text { Mn-ICG@pHis-PEG/GA } \\
\text { nanofibers }\end{array}$ & $\begin{array}{l}\text { In vitro and } \\
\text { in vivo }\end{array}$ & Magnetic target moiety: $\mathrm{Fe} 3 \mathrm{O} 4$ & Breast cancer & $4 \mathrm{TI}$ cells & [115] \\
\hline Nanorods & GNR/TiO2 nanorods & In vitro & $\begin{array}{l}\text { Folate receptor- target moiety: } \\
\text { folic acid (FA) }\end{array}$ & Glioblastoma & U-87 MG cells & [117] \\
\hline Nanocomplex & $\begin{array}{l}\mathrm{HA}(\mathrm{CD})-4 \mathrm{Phe} 4 \\
\text { nanocomplex }\end{array}$ & In vitro & $\begin{array}{l}\text { pH sensitive moiety: poly } \\
\text { (L-histidine) (pHis) }\end{array}$ & Melanoma cells & MDA-MB-435/MDR cells & [118] \\
\hline $\begin{array}{l}\text { Quantum } \\
\text { dots }\end{array}$ & CdTe QDs & In vitro & & $\begin{array}{l}\text { Hepatic } \\
\text { carcinoma }\end{array}$ & HepG2 cells & {$[120]$} \\
\hline Liposomes & GA liposomes & $\begin{array}{l}\text { In vitro and } \\
\text { in vivo }\end{array}$ & CD44-target moiety: HA & Breast cancer & MDA-MB-23I cells & [130] \\
\hline
\end{tabular}

Photodynamic therapy (PDT) as a noninvasive therapeutic approach for cancer treatment relies on photosensitizers to generate cytotoxic ROS resulting in the tumor cells apoptosis, which exhibited significant advantages of selective cytotoxicity to tumor cells and few side effects on normal tissues. ${ }^{98}$ Liang et al prepared an amphipathic prodrug of GA-grafted HA to encapsulate the photosensitizer chlorin e6 (Ce6) forming amphipathic nanomicelles (HA-GA@Ce6), which showed stronger cell uptake in 4T1 tumor cells and superior anti-tumor efficacy by reducing intracellular antioxidant levels. ${ }^{99}$

\section{Nanoparticles}

Magnetic $\mathrm{Fe}_{3} \mathrm{O}_{4}$ nanoparticles (MNP $\mathrm{Fe}_{3} \mathrm{O}_{4}$ ), a promising candidate owning biocompatible and superparamagnetic properties, have been widely studied as targeted drug delivery systems with satisfactory stability and low toxicity in the field of cancer therapy. ${ }^{100}$ Wang et al constructed the GA-loaded $\mathrm{MNP}-\mathrm{Fe}_{3} \mathrm{O}_{4}$ by mechanical absorption polymerization, which demonstrated a remarkable potential in inducing apoptosis on Capan-1 pancreatic cancer cells. Besides, the findings showed that the synergistic anti-cancer effects might associate with the mechanisms of reducing protein expression of Bcl-2 and enhancing proapoptotic gene products of Bax, caspase 9 and caspase $3 .{ }^{101}$ In addition, MNP$\mathrm{Fe}_{3} \mathrm{O}_{4}$ was also considered as a promising drug carrier for GA in suppressing ETS1-mediated cell proliferation and migration on to Panc-1 pancreatic cancer cells. ${ }^{102}$ Chen et al discovered that $\mathrm{MNP}-\mathrm{Fe}_{3} \mathrm{O}_{4}$ dramatically enhanced apoptosis induction and cytotoxicity of GA in K562 cells, accompanied with the regulation of caspase-3, bax, bcl-2,

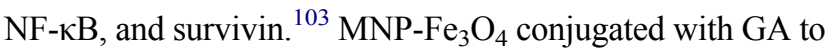


enhance the chemotherapeutic efficiency in Capan-1 pancreatic cancer cells via regulating the apoptosis pathway related gene products, including Bax, Bcl-2, caspase 9, and caspase 3. ${ }^{101}$ Furthermore, the combination therapy of MNP$\mathrm{Fe}_{3} \mathrm{O}_{4}$ and GA was also evidenced in LOVO human colon cancer cells by the regulation of the $\mathrm{PI} 3 \mathrm{~K} / \mathrm{Akt} / \mathrm{Bad}$ pathway. $^{104}$

Hypoxia-targeting near-infrared dye (Cy7) moiety was conjugated to GA, which could self-assemble into the novel "mosaic-type" nanoparticles with surfactin in the aqueous solution for selective drug release targeting hypoxic cancer cells in order to decrease nonspecific accumulation in the liver and improve antitumor efficacy. ${ }^{105}$ The anti-EGFRiRGD recombinant protein was modified on the surface of red blood cell membrane-coated nanoparticles (RBCm-NPs) that loaded the potential anti-tumor drug GA to improve antitumor efficiency with the reduction of the side effects of GA and ensuring the safety in colorectal cancer models. ${ }^{106}$ Zhang et al also evidenced that GA-loaded polyethylene glycol (PEG)-polycaprolactone (PCL) nanoparticles exhibited superior antitumor activity compared with free GA in gastric cancer using nanoparticles to encapsulate drugs. ${ }^{107}$ The nanoparticles that combined poly(lactic-co-glycolic acid) (PLGA) with RBCm were utilized to deliver GA, which exhibited a certain antitumor efficacy and notable tumor inhibition with relatively lower toxicity compared with free GA in colorectal cancer treatment. ${ }^{108}$ Wang et al constructed the HA-coated CD44-targeted nanoparticles to co-deliver GA and tumor necrosis factor-related apoptosisinducing ligand (TRAIL) in triple negative breast cancer treatment, showing the augmented pro-apoptotic effects in vitro and tumor suppression in vivo. ${ }^{109}$ Folate receptor (FR) was overexpressed on poorly differentiated and more aggressive tumors, bound with FA and to transport them via the nonclassical endocytic way. FA decorated arginine-based poly(ester urea urethane) (FA-Arg-PEUUs) conjugates were utilized to deliver GA, resulting in the higher cytotoxicity, apoptosis percentage, mitochondrial membrane potential disruption and DNA fragmentation compared to free drug on cancer cells. $^{110}$

RBCm was introduced into synthetic biomimetic nanocarriers, which could evade the mononuclear phagocyte response to prolong systemic circulation and reduce the uptake of reticuloendothelial system. ${ }^{111}$ Zhang et al established the RBCm-GA/PLGA drug delivery systems with good biocompatibility and drug solubilizing capacity, providing the significant reduction in tumor volume size in vivo for colorectal cancer treatment. ${ }^{108}$ Moreover, human serum albumin (HSA) with low toxicity was designed to bring into the nanoparticles that helped with improving drug solubility, increasing retention in the tumor interstitium and improving the anticancer efficacy in delivering GA. ${ }^{112}$

\section{Nano-Spheres}

F68 was conjugated with linoleic acids (LA) to form nanospheres with a hydrophobic core in order to incorporate GA. Fang et al showed further evidence that the pluronic F68-linoleic acid nano-spheres induced enhanced higher cytotoxicity and apoptosis against ovarian cancer A2780 cells, which were considered as a potential delivery system for GA in the field of ovarian cancer treatment. ${ }^{113}$

\section{Nanofibers and Nanorods}

Photothermal therapy (PTT) is one kind of cancer therapy that has attracted tremendous attention, which works through generating hyperthermia under near-infrared (NIR) light to ablate tumors. ${ }^{114}$ Yang et al fabricated novel PEGylated one-dimensional nanoscale coordination polymers (1D-NCPs) to load GA to enhance tumor destruction efficacy by low-temperature PTT, showing the tumor-specific $\mathrm{pH}$ responsiveness and theranostic functionalities of GA nanoparticles accompanied by a unique perspective to kill cancer. ${ }^{115}$

Gold nanorods (GNRs) as one kind of gold nanostructure, have been extensively studied by researchers owing to the unique plasmonic properties, which could penetrate deeply into tissues and were deemed as a candidate agent for in vivo imaging and therapy. ${ }^{116}$ Titanium dioxide (TiO2)-coated GNR (GNR/TiO2) nanostructures were constructed as a carrier for GA, induced a higher intracellular drug content and superior cytotoxicity under $808 \mathrm{~nm}$ NIR laser irradiation due to the synergistic PPT and chemotherapy. ${ }^{117}$

\section{Nanocomplex}

The biodegradable inclusion complex was developed by $\beta$ cyclodextrin grafted $\mathrm{HA}(\mathrm{HA}(\mathrm{CD}))$ and phenylalanine based poly(ester amide)s (4Phe4), which were enabled to target the overexpressed CD44 receptors on tumor cells and loaded with the hydrophobic GA to improve the therapeutic effect. The results evidenced that the HA(CD)-4Phe4 nanocomplex significantly induced apoptotic cell death and effectively inhibited tumor metastasis via suppressing the MMP activities in MDA-MB-435/MDR cells. ${ }^{118}$ 


\section{Quantum Dots}

Quantum dots (QDs) have been applied in the fields of biological and clinical applications, including labeling, targeted drug delivery, imaging and photodynamic therapy. ${ }^{119}$ The novel fluorescent nanocomposites based on GA and cadmium-tellurium (CdTe) quantum dots (CdTe QDs) were prepared, which induced G2/M phase arrest and apoptosis in HepG2 cells as well as remarkably reduced side effects of GA on normal cells/tissues given the $\mathrm{pH}$ sensitive mechanism. ${ }^{120}$

\section{Combination Therapy}

The combination therapy of GA and cisplatin showed the synergistic effects of suppression of tumorigenesis in human osteosarcoma treatment via inducing the cell cycle arrest and promoting mitochondria-independent cell apoptosis. ${ }^{131}$ The combined application of GA and docetaxel also showed a synergistic anti-tumor effect in gastrointestinal cancer cells, possibly related to the suppression of mRNA expression, including $\beta$-tubulin III, tau and surviving. ${ }^{132}$ Wang et al made similar findings of the synergistic effect of 5-fluorouracil and GA on BGC823 human gastric carcinoma, with the underlying mechanism of the gene expressions of thymidine synthetase (TS), dihydropyrimidine dehydrogenase (DPD) and orotate phosphoribosyltransferase (OPRT) regulated by GA, which played a vital role in the 5-FU metabolic procession. ${ }^{133}$

Nanoparticles possess many excellent properties that have been widely investigated as drug delivery carriers. GA and retinoic acid chlorochalcone (RACC) were simultaneously loaded in glycol chitosan nanoparticles for combination cancer chemotherapy against osteosarcoma cancer cells, which induced a higher apoptosis rate of MG63 cancer cells with $28 \% .{ }^{127}$ Besides, the folate-modified carboxymethyl-chitosan/polyethylenimine/bovine serum albumin based nanoparticles were used to co-deliver GA and TRAIL, which embodied the combined tumor therapy by regulating both intrinsic and extrinsic apoptotic pathways. ${ }^{123}$ The amphiphilic conjugate constructed by HA and all-trans retinoic acid (ATRA) was applied to entrapped GA for reducing tumor volume and side effects also via the combination therapy strategy. ${ }^{129}$ The combination of drugs and gene therapy for the treatment of cancer presents great potential advantages due to the reduction of side effects, the synergistic/combined antitumor effects and the ability of overcoming drug resistance. GA was conjugated with poly(amido amine)s (PAAs) through amide bonds to establish a novel redox-sensitive system for co-delivering docetaxel and MMP-9 shRNA, which could rapidly trigger and simultaneously release the docetaxel (DTX), GA and MMP-9 shRNA in response to cytoplasmic reducing reagents resulting in greater anti-tumor efficacy. ${ }^{121}$ Moreover, Zhou et al synthesized cysteaminemodified cadmium tellurium (Cys-CdTe) quantum dots to load daunorubicin (DNR) and GA to reduce the side effects and multidrug resistance (MDR) generated from DNR chemotherapy of malignant lymphoma, which could downregulate the expression of P-glycoprotein on Raji/DNR cells resulting in minimizing MDR. ${ }^{134}$ It was reported that GA and DTX could simultaneously release from PLGA nanoparticles, showing the synergistic antitumor effect attributed to the reversion of multidrug resistance of MCF-7/ADR cells to DTX and inducing cell apoptosis through downregulating the expression of P-gp. ${ }^{126}$

The combination therapy of chemotherapeutic drug and antiangiogenesis agent was designed to inhibit tumor proliferation and invasion while establishing a dual-targeted and multifunctional polymeric nanosystem. Dahmani et al synthesized an amphiphilic c(RGDyK)-functionalized conjugate consisting of LMWH and GA, which could target both tumor cells and angiogenic vasculature, accompanied with increasing accumulation of drugs within the tumor site. ${ }^{128}$

\section{Conclusion}

In this review, the evidence given above supports that GA has great potential in multiple cancer treatments. We discussed and summarized GA in many ways, including the chemical properties, underlying molecular mechanisms, anticancer activities, drug resistance, combinational influence, and novel drug delivery systems based on nanotechnology. Numerous facts were well proven, that GA had various anticancer properties both in vitro and in vivo, including triggering apoptosis, inducing autophagy and cell cycle arrest, inhibiting invasion, metastasis and angiogenesis, and so forth. Multiple novel drug delivery systems of GA including micelles, nanoparticles, nanofibers, and nanorods, have been developed with the purpose of increasing the solubility, prolonging circulation, triggering drug release via responsive manner, reducing side effects and enhancing the drug therapeutic effect. Despite the novel techniques utilized in GA being studied in treating cancer, there was little development in the clinical application of GA and new formulations because of the complicated process to produce them and the lack of clinical trials of these GA formulations during 
the pharmaceutical research. The structure of the xanthone moiety in GA still needs to be explored in the future and utilized to develop more active derivatives in treating diseases. Meanwhile, it is vital that more chances to explore and find more unknown properties of GA are pursued in the future. In sum, it is expected that more and more attention can be paid to the development of GA in multiple aspects, especially in the field of clinical application, which will lead to a breakthrough and better treatments in future.

\section{Acknowledgments}

This study was supported by the National Natural Science Foundation of China (81803743), the Basic Research Foundation of the China Academy of Chinese Medical Sciences (ZZ13-YQ-041), and the National Major Scientific and Technological Special Project for “Significant New Drugs Development" (2019ZX09301160, 2019ZX09721001-005-002).

\section{Disclosure}

The authors report no conflicts of interest in this work.

\section{References}

1. Zhang Y, Li M, Gao X, Chen Y, Liu T. Nanotechnology in cancer diagnosis: progress, challenges and opportunities. J Hematol Oncol. 2019;12(1):137. doi:10.1186/s13045-019-0833-3

2. Banik K, Harsha C, Bordoloi D, et al. Therapeutic potential of gambogic acid, a caged xanthone, to target cancer. Cancer Lett. 2018;416:75-86. doi:10.1016/j.canlet.2017.12.014

3. Zhou BD, Weng ZM, Tong YG, et al. Syntheses of xanthone derivatives and their bioactivity investigation. $J$ Asian Nat Prod Res. 2020;1-13.

4. Kashyap D, Mondal R, Tuli HS, Kumar G, Sharma AK. Molecular targets of gambogic acid in cancer: recent trends and advancements. Tumour Biol. 2016;37(10):12915-12925.

5. Han QB, Cheung S, Tai J, Qiao CF, Song JZ, Xu HX. Stability and cytotoxicity of gambogic acid and its derivative, gambogoic acid. Biol Pharm Bull. 2005;28(12):2335-2337.

6. Wen CY, Huang LL, Chen JX, et al. Gambogic acid inhibits growth, induces apoptosis, and overcomes drug resistance in human colorectal cancer cells. Int $J$ Oncol. 2015;47 (5):1663-1671.

7. Wang YY, Zhang XJ, Yang YR, Sun HP, You QD. Progress in research of the structural optimization of natural product-like Garcinia caged xanthones. Үао Хие Хие Вао. 2014;49 (3):293-302.

8. Youns M, ElKhoely A, Kamel R. The growth inhibitory effect of gambogic acid on pancreatic cancer cells. N-S Arch Pharmacol. 2018;391(5):551-560.

9. Wang J, Shen W, Yuan ZL, et al. Michael acceptor in gambogic acid-its role and application for potent antitumor agents. Bioorg Med Chem Lett. 2015;25(14):2844-2848.

10. Chen J, Gu H-Y, Lu N, et al. Microtubule depolymerization and phosphorylation of c-Jun N-terminal kinase-1 and p38 were involved in gambogic acid induced cell cycle arrest and apoptosis in human breast carcinoma MCF-7 cells. Life Sci. 2008;83(3-4):103-109. doi:10.1016/j.lfs.2008.05.003
11. Li R, Chen Y, Zeng -L-L, et al. Gambogic acid induces G0/G1 arrest and apoptosis involving inhibition of SRC-3 and inactivation of Akt pathway in K562 leukemia cells. Toxicology. 2009;262(2):98-105. doi:10.1016/j.tox.2009.04.059

12. Wang JX, Zhao L, Hu Y, et al. Studies on chemical structure modification and biology of a natural product, Gambogic acid (I): synthesis and biological evaluation of oxidized analogues of gambogic acid. Eur J Med Chem. 2009;44(6):2611-2620. doi:10.1016/j.ejmech.2008.09.034

13. Zhang H-Z, Kasibhatla S, Wang Y, et al. Discovery, characterization and SAR of gambogic acid as a potent apoptosis inducer by a HTS assay. Bioorg Med Chem. 2004;12(2):309-317. doi:10.1016/j.bmc.2003.11.013

14. Palempalli UD, Gandhi U, Kalantari P, et al. Gambogic acid covalently modifies IKB kinase- $\beta$ subunit to mediate suppression of lipopolysaccharide-induced activation of NF- $\mathrm{KB}$ in macrophages. Biochem J. 2009;419(2):401-409. doi:10.1042/ BJ20081482

15. Yang J, Li C, Ding L, Guo Q, You Q, Jin S. Gambogic acid deactivates cytosolic and mitochondrial thioredoxins by covalent binding to the functional domain. $J$ Nat Prod. 2012;75 (6):1108-1116. doi:10.1021/np300118c

16. Hong B, van den Heuvel AP, Prabhu VV, Zhang S, El-Deiry WS. Targeting tumor suppressor p53 for cancer therapy: strategies, challenges and opportunities. Curr Drug Targets. 2014;15 (1):80-89. doi:10.2174/1389450114666140106101412

17. Goldar S, Khaniani MS, Derakhshan SM, Baradaran B. Molecular mechanisms of apoptosis and roles in cancer development and treatment. Asian Pac J Cancer Prev. 2015;16 (6):2129-2144. doi:10.7314/APJCP.2015.16.6.2129

18. Zhai DY, Jin CF, Shiau C-W, Kitada S, Satterthwait AC, Reed JC. Gambogic acid is an antagonist of antiapoptotic Bcl-2 family proteins. Mol Cancer Ther. 2008;7(6):1639-1646. doi:10.1158/ 1535-7163.MCT-07-2373

19. Gu HY, Rao SY, Zhao J, et al. Gambogic acid reduced bcl-2 expression via p53 in human breast MCF-7 cancer cells. J Cancer Res Clin. 2009;135(12):1777-1782. doi:10.1007/ s00432-009-0624-2

20. Gu HY, Wang XT, Rao SY, et al. Gambogic acid mediates apoptosis as a p53 inducer through down-regulation of $\mathrm{mdm} 2$ in wild-type p53-expressing cancer cells. Mol Cancer Ther. 2008;7 (10):3298-3305. doi:10.1158/1535-7163.MCT-08-0212

21. Rong -J-J, Hu R, Qi Q, et al. Gambogic acid down-regulates MDM2 oncogene and induces p21Waf1/CIP1 expression independent of p53. Cancer Lett. 2009;284(1):102-112. doi:10.1016/ j.canlet.2009.04.011

22. Wang J, Zhao Q, Qi Q, et al. Gambogic acid-induced degradation of mutant p53 is mediated by proteasome and related to CHIP. J Cell Biochem. 2011;112(2):509-519. doi:10.1002/jcb.22941

23. Davenport J, Manjarrez JR, Peterson L, Krumm B, Blagg BSJ, Matts RL. Gambogic acid, a natural product inhibitor of Hsp90. J Nat Prod. 2011;74(5):1085-1092. doi:10.1021/ np200029q

24. Zhang LR, Yi YT, Chen JJ, et al. Gambogic acid inhibits Hsp90 and deregulates TNF- $\alpha / \mathrm{NF}-\kappa \mathrm{B}$ in HeLa cells. Biochem Bioph Res Co. 2010;403(3-4):282-287. doi:10.1016/j.bbrc.2010.11.018

25. Felth J, Lesiak-Mieczkowska K, D'Arcy P, et al. Gambogic acid is cytotoxic to cancer cells through inhibition of the ubiquitin-proteasome system. Invest New Drug. 2013;31 (3):587-598. doi:10.1007/s10637-012-9902-y

26. Li XF, Liu ST, Huang HB, et al. Gambogic acid is a tissue-specific proteasome inhibitor in vitro and in vivo. Cell Rep. 2013;3(1):211-222. doi:10.1016/j.celrep.2012.11.023

27. Shi XP, Lan XY, Chen X, et al. Gambogic acid induces apoptosis in diffuse large B-cell lymphoma cells via inducing proteasome inhibition. Sci Rep-Uk. 2015;5. 
28. Ruiz-Ruiz C, Lopez-Rivas A. Mitochondria-dependent and independent mechanisms in tumour necrosis factor-related apoptosis-inducing ligand (TRAIL)-induced apoptosis are both regulated by interferon-gamma in human breast tumour cells. Biochem J. 2002;365(3):825-832.

29. Smith DJ, Ng H, Kluck RM, Nagley P. The mitochondrial gateway to cell death. IUBMB Life. 2008;60(6):383-389.

30. Guizzunti G, Batova A, Chantarasriwong O, Dakanali M, Theodorakis EA. Subcellular localization and activity of gambogic acid. Chembiochem. 2012;13(8):1191-1198.

31. Li CL, Qi Q, Lu N, et al. Gambogic acid promotes apoptosis and resistance to metastatic potential in MDA-MB-231 human breast carcinoma cells. Biochem Cell Biol. 2012;90(6):718-730.

32. Yang J, Li CL, Ding L, Guo QL, You QD, Jin SH. Gambogic acid deactivates cytosolic and mitochondrial thioredoxins by covalent binding to the functional domain. J Nat Prod. 2012;75(6):1108-1116.

33. Yang LJ, Chen Y, He J, et al. Effects of gambogic acid on the activation of caspase-3 and downregulation of SIRT1 in RPMI-8226 multiple myeloma cells via the accumulation of ROS. Oncol Lett. 2012;3(5):1159-1165.

34. Rahman MA, Kim NH, Huh SO. Cytotoxic effect of gambogic acid on SH-SY5Y neuroblastoma cells is mediated by intrinsic caspase-dependent signaling pathway. Mol Cell Biochem. 2013;377(1-2):187-196.

35. Lee PNH, Ho WS. Antiproliferative activity of gambogic acid isolated from Garcinia hanburyi in Hep3B and Huh7 cancer cells. Oncol Rep. 2013;29(5):1744-1750.

36. Huang GM, Sun Y, Ge X, Wan X, Li CB. Gambogic acid induces apoptosis and inhibits colorectal tumor growth via mitochondrial pathways. World J Gastroentero. 2015;21(20):6194-6205.

37. Thida M, Kim DW, Tran TTT, et al. Gambogic acid induces apoptotic cell death in T98G glioma cells. Bioorg Med Chem Lett. 2016;26(3):1097-1101.

38. Nie FF, Zhang XN, Qi Q, et al. Reactive oxygen species accumulation contributes to gambogic acid-induced apoptosis in human hepatoma SMMC-7721 cells. Toxicology. 2009;260(1-3):60-67.

39. Duan DZ, Zhang BX, Yao J, et al. Gambogic acid induces apoptosis in hepatocellular carcinoma SMMC-7721 cells by targeting cytosolic thioredoxin reductase. Free Radical Bio Med. 2014;69:15-25.

40. Zhu XL, Zhang HM, Lin Y, et al. Mechanisms of gambogic acid-induced apoptosis in non-small cell lung cancer cells in relation to transferrin receptors. J Chemother. 2009;21(6):666-672.

41. Kasibhatla S, Jessen KA, Maliartchouk S, et al. A role for transferrin receptor in triggering apoptosis when targeted with gambogic acid. P Natl Acad Sci USA. 2005;102(34):12095-12100.

42. Pandey MK, Sung B, Ahn KS, Kunnumakkara AB, Chaturvedi MM, Aggarwal BB. Gambogic acid, a novel ligand for transferrin receptor, potentiates TNF-induced apoptosis through modulation of the nuclear factor-kappa B signaling pathway. Blood. 2007;110(10):3517-3525.

43. Tang QS, Lu MD, Zhou H, Chen DZ, Liu L. Gambogic acid inhibits the growth of ovarian cancer tumors by regulating p65 activity. Oncol Lett. 2017;13(1):384-388.

44. Chen JH, Zhou M, Zhang Q, Xu JY, Ouyang J. Anticancer effect and apoptosis induction of gambogic acid in human leukemia cell line K562 in vitro. Med Sci Mon. 2015;21:1604-1610.

45. Liu WY, Wu X, Liao CQ, Shen J, Li J. Apoptotic effect of gambogic acid in esophageal squamous cell carcinoma cells via suppression of the NF-kappa B pathway. Oncol Lett. 2016;11 (6):3681-3685.

46. Prasad S, Pandey MK, Yadav VR, Aggarwal BB. Gambogic acid inhibits STAT3 phosphorylation through activation of protein tyrosine phosphatase SHP-1: potential role in proliferation and apoptosis (Retracted article. See vol. 11, pg. 593, 2018). Cancer Prev Res. 2011;4(7):1084-1094.
47. Pan H, Lu LY, Wang XQ, Li BX, Kelly K, Lin HS. Gambogic acid induces cell apoptosis and inhibits MAPK pathway in PTEN-/-/p53(-/-) prostate cancer cells in vitro and ex vivo. Chin J Integr Med. 2018;24(2):109-116.

48. Song HH, Li Y, Ma Y, Ling SK, Ge Z, Huang PL. Induced apoptosis in multiple myeloma cells expressing miR-21 through AKT/FOXO1/BIM signaling. Nanosci Nanotech Let. 2018;10 (7):1006-1012.

49. Zhu MH, Wang MJ, Jiang YF, et al. Gambogic acid induces apoptosis of non-small cell lung cancer (NSCLC) cells by suppressing notch signaling. Med Sci Mon. 2018;24:7146-7151.

50. Zhang CH, Liu J, Tao FX, et al. The nuclear export of TR3 mediated gambogic acid-induced apoptosis in cervical cancer cells through mitochondrial dysfunction. RSC Adv. 2019;9 (21):11855-11864.

51. Li R, Chen Y, Shu WX, Zhao F, Liu Y, Wen L. Effects of gambogic acid on regulation of steroid receptor coactivator-3 in lung adenocarcinoma A549 cells. Chinese J Cancer Res. 2009;21 (1):68-73.

52. Cui GH, Shu WX, Wu Q, Chen Y. Effect of gambogic acid on the regulation of hERG channel in K562 cells in vitro. J Huazhong U Sci-Med. 2009;29(5):540-545.

53. Wang YH, Wang W, Sun HQ. Bromodomain-containing protein 4 is critical for the antiproliferative and pro-apoptotic effects of gambogic acid in anaplastic thyroid cancer. Int $J \mathrm{Mol}$ Med. 2018;42(1):161-170.

54. He XY, Liu XJ, Chen X, et al. Gambogic acid induces EGFR degradation and Akt/mTORC1 inhibition through AMPK dependent-LRIG1 upregulation in cultured U87 glioma cells. Biochem Bioph Res Co. 2013;435(3):397-402.

55. Gu HG, You QD, Liu W, et al. Gambogic acid induced tumor cell apoptosis by $\mathrm{T}$ lymphocyte activation in $\mathrm{H}-22$ transplanted mice. Int Immunopharmacol. 2008;8(11):1493-1502.

56. Zhao W, Zhou SF, Zhang ZP, Xu GP, Li XB, Yan JL. Gambogic acid inhibits the growth of osteosarcoma cells in vitro by inducing apoptosis and cell cycle arrest. Oncol Rep. 2011;25 (5):1289-1295.

57. Ye LJ, Zhou JM, Zhao W, Jiao PF, Ren GF, Wang SJ. Gambogic acid-induced autophagy in nonsmall cell lung cancer NCI-H441 cells through a reactive oxygen species pathway. $J$ Cancer Res Ther. 2018;14:S942-S947.

58. Luo GX, Cai J, Lin JZ, et al. Autophagy inhibition promotes gambogic acid-induced suppression of growth and apoptosis in glioblastoma cells. Asian Pac $J$ Cancer $P$. 2012;13 (12):6211-6216.

59. Zhao T, Wang HJ, Zhao WW, Sun YL, Hu LK. Gambogic acid improves non-small cell lung cancer progression by inhibition of mTOR signaling pathway. Kaohsiung J Med Sci. 2017;33 (11):543-549.

60. Foggetti G, Ottaggio L, Russo D, et al. Gambogic acid counteracts mutant p53 stability by inducing autophagy. Bba-Mol Cell Res. 2017;1864(2):382-392.

61. Zhang HY, Lei YL, Yuan P, et al. ROS-mediated autophagy induced by dysregulation of lipid metabolism plays a protective role in colorectal cancer cells treated with gambogic acid. PLoS One. 2014;9(5).

62. Ishaq M, Khan MA, Sharma K, Sharma G, Dutta RK, Majumdar S. Gambogic acid induced oxidative stress dependent caspase activation regulates both apoptosis and autophagy by targeting various key molecules (NF-kappa B, Beclin-1, p62 and NBR1) in human bladder cancer cells. Bba-Gen Subjects. 2014;1840(12):3374-3384.

63. Gao GY, Bian YZ, Qian HQ, et al. Gambogic acid regulates the migration and invasion of colorectal cancer via microRNA-21mediated activation of phosphatase and tensin homolog. Exp Ther Med. 2018;16(3):1758-1765. 
64. Zhao K, Zhang S, Song XM, et al. Gambogic acid suppresses cancer invasion and migration by inhibiting TGF beta 1-induced epithelial-to-mesenchymal transition. Oncotarget. 2017;8 (16):27120-27136.

65. Qi Q, Lu N, Li CL, et al. Involvement of RECK in gambogic acid induced anti-invasive effect in A549 human lung carcinoma cells. Mol Carcinogen. 2015;54:E13-E25.

66. Qi Q, Gu HY, Yang Y, et al. Involvement of matrix metalloproteinase 2 and 9 in gambogic acid induced suppression of MDA-MB-435 human breast carcinoma cell lung metastasis. J Mol Med. 2008;86(12):1367-1377.

67. Qi Q, Lu N, Wang XT, et al. Anti-invasive effect of gambogic acid in MDA-MB-231 human breast carcinoma cells. Biochem Cell Biol. 2008;86(5):386-395.

68. Park MS, Kim NH, Kang CW, Oh CW, Kim GD. Antimetastatic effects of gambogic acid are mediated via the actin cytoskeleton and NF-B pathways in SK-HEP1 cells. Drug Develop Res. 2015;76(3):132-142.

69. Lu L, Tang D, Wang L, et al. Gambogic acid inhibits TNF-alphainduced invasion of human prostate cancer PC3 cells in vitro through PI3K/Akt and NF-kappa B signaling pathways. Acta Pharmacol Sin. 2012;33(4):531-541.

70. Xin ZF, Shen CC, Tao LJ, Yan SG, Wu HB. Gambogic acid inhibits invasion of osteosarcoma via upregulation of TIMP-1. Int J Mol Med. 2013;31(1):105-112.

71. Zhao J, Qi Q, Yang Y, et al. Inhibition of alpha(4) integrin mediated adhesion was involved in the reduction of B16-F10 melanoma cells lung colonization in C57BL/6 mice treated with Gambogic acid. Eur J Pharmacol. 2008;589(1-3):127-131.

72. Zhang H, Wang Z, Peng Q, et al. Tumor refractoriness to endostatin anti-angiogenesis is associated with the recruitment of $\mathrm{CD} 11 \mathrm{~b}+\mathrm{Gr} 1+$ myeloid cells and inflammatory cytokines. Tumori. 2013;99(6):723-733.

73. Wang F, Zhang W, Guo LT, et al. Gambogic acid suppresses hypoxia-induced hypoxia-inducible factor-1/vascular endothelial growth factor expression via inhibiting phosphatidylinositol 3-kinase/Akt/mammalian target protein of rapamycin pathway in multiple myeloma cells. Cancer Sci. 2014;105(8):1063-1070.

74. Lu N, Hui H, Yang H, et al. Gambogic acid inhibits angiogenesis through inhibiting PHD2-VHL-HIF-1 alpha pathway. Eur J Pharm Sci. 2013;49(2):220-226.

75. Yi T, Yi Z, Cho SG, et al. Gambogic acid inhibits angiogenesis and prostate tumor growth by suppressing vascular endothelial growth factor receptor 2 signaling. Cancer Res. 2008;68 (6): 1843-1850.

76. Assaraf YG, Brozovic A, Goncalves AC, et al. The multi-factorial nature of clinical multidrug resistance in cancer. Drug Resist Updat. 2019;46:100645.

77. Wang Q, Wei JC, Wang CX, et al. Gambogic acid reverses oxaliplatin resistance in colorectal cancer by increasing intracellular platinum levels. Oncol Lett. 2018;16(2):2366-2372.

78. Xia GG, Wang HC, Song ZL, Meng QC, Huang XY, Huang XY. Gambogic acid sensitizes gemcitabine efficacy in pancreatic cancer by reducing the expression of ribonucleotide reductase subunit-M2 (RRM2). J Exp Clin Canc Res. 2017;36.

79. Zhao W, Xia SQ, Zhuang JP, et al. Hypoxia-induced resistance to cisplatin-mediated apoptosis in osteosarcoma cells is reversed by gambogic acid independently of HIF-1 alpha. Mol Cell Biochem. 2016;420(1-2):1-8.

80. Wang SP, Wang L, Chen MW, Wang YT. Gambogic acid sensitizes resistant breast cancer cells to doxorubicin through inhibiting P-glycoprotein and suppressing survivin expression. Chem-Biol Interact. 2015;235:76-84.

81. Wang TT, Wei J, Qlan XP, Ding YT, Yu LX, Liu BR. Gambogic acid, a potent inhibitor of survivin, reverses docetaxel resistance in gastric cancer cells. Cancer Lett. 2008;262(2):214-222.
82. Wang CD, Wang W, Wang CY, Tang YJ, Tian H. Combined therapy with EGFR TKI and gambogic acid for overcoming resistance in EGFR-T790M mutant lung cancer. Oncol Lett. 2015;10(4):2063-2066.

83. Xia Y, Zhong J, Zhao M, et al. Galactose-modified selenium nanoparticles for targeted delivery of doxorubicin to hepatocellular carcinoma. Drug Deliv. 2019;26(1):1-11.

84. Xia Y, Tang G, Wang C, et al. Functionalized selenium nanoparticles for targeted siRNA delivery silence Derlin1 and promote antitumor efficacy against cervical cancer. Drug Deliv. 2020;27 (1):15-25.

85. Xia Y, Tang G, Guo M, et al. Silencing KLK12 expression via RGDfC-decorated selenium nanoparticles for the treatment of colorectal cancer in vitro and in vivo. Mater Sci Eng C Mater Biol Appl. 2020;110:110594.

86. Yu G, Ning Q, Mo Z, Tang S. Intelligent polymeric micelles for multidrug co-delivery and cancer therapy. Artif Cells Nanomed Biotechnol. 2019;47(1):1476-1487.

87. Hwang D, Ramsey JD, Kabanov AV. Polymeric micelles for the delivery of poorly soluble drugs: from nanoformulation to clinical approval. Adv Drug Deliv Rev. 2020.

88. Attia ABE, Ong ZY, Hedrick JL, et al. Mixed micelles self-assembled from block copolymers for drug delivery. Curr Opin Colloid Interface Sci. 2011;16(3):182-194.

89. Saxena V, Hussain MD. Poloxamer 407/TPGS mixed micelles for delivery of gambogic acid to breast and multidrug-resistant cancer. Int J Nanomed. 2012;7:713-721.

90. Yu F, Jiang FG, Tang XH, Wang BC. N-octyl-N-arginine-chitosan micelles for gambogic acid intravenous delivery: characterization, cell uptake, pharmacokinetics, and biodistribution. Drug Dev Ind Pharm. 2018;44(4):615-623.

91. Wang SP, Yang Y, Wang YT, Chen MW. Gambogic acid-loaded $\mathrm{pH}$-sensitive mixed micelles for overcoming breast cancer resistance. Int J Pharmaceut. 2015;495(2):840-848.

92. Wang Y, Liang XFQ, Tong RS, et al. Gambogic acid-loaded polymeric micelles for improved therapeutic effect in breast cancer. J Biomed Nanotechnol. 2018;14(10):1695-1704.

93. Yu F, He CH, Waddad AY, et al. N-octyl-N-arginine-chitosan (OACS) micelles for gambogic acid oral delivery: preparation, characterization and its study on in situ intestinal perfusion. Drug Dev Ind Pharm. 2014;40(6):774-782.

94. Sang MM, Liu FL, Wang $\mathrm{Y}$, et al. A novel redox/pH dual-responsive and hyaluronic acid-decorated multifunctional magnetic complex micelle for targeted gambogic acid delivery for the treatment of triple negative breast cancer. Drug Deliv. 2018;25(1):1846-1857.

95. Ke ZC, Yang L, Wu H, Li ZH, Jia XB, Zhang ZH. Evaluation of in vitro and in vivo antitumor effects of gambogic acid-loaded layer-by-layer self-assembled micelles. Int $J$ Pharmaceut. 2018;545(1-2):306-317.

96. Yan XF, Yang Y, He LQ, Peng DY, Yin DK. Gambogic acid grafted low molecular weight heparin micelles for targeted treatment in a hepatocellular carcinoma model with an enhanced anti-angiogenesis effect. Int $J$ Pharmaceut. 2017;522 (1-2):110-118.

97. Xu YQ, Wang SP, Chan HF, et al. Triphenylphosphoniummodified poly(ethylene glycol)-poly(epsilon-caprolactone) micelles for mitochondria- targeted gambogic acid delivery. Int J Pharmaceut. 2017;522(1-2):21-33.

98. Luo S, Tan X, Fang S, et al. MItochondria-targeted small-molecule fluorophores for dual modal cancer phototherapy. Adv Funct Mater. 2016;26(17):2826-2835.

99. Liang H, Zhou ZW, Luo RJ, et al. Tumor-specific activated photodynamic therapy with an oxidation-regulated strategy for enhancing anti-tumor efficacy. Theranostics. 2018;8 (18):5059-5071. 
100. Vangijzegem T, Stanicki D, Laurent S. Magnetic iron oxide nanoparticles for drug delivery: applications and characteristics. Expert Opin Drug Deliv. 2019;16(1):69-78. doi:10.1080/ 17425247.2019.1554647

101. Wang CL, Zhang HJ, Chen BA, Yin HT, Wang WW. Study of the enhanced anticancer efficacy of gambogic acid on Capan-1 pancreatic cancer cells when mediated via magnetic $\mathrm{Fe} 3 \mathrm{O} 4$ nanoparticles. Int J Nanomed. 2011;6:1929-1935.

102. Wang CL, Zhang HJ, Chen Y, Shi FF, Chen BA. Gambogic acid-loaded magnetic Fe3O4 nanoparticles inhibit Panc-1 pancreatic cancer cell proliferation and migration by inactivating transcription factor ETS1. Int J Nanomed. 2012;7:781-787.

103. Chen BA, Liang $\mathrm{Y}, \mathrm{Wu} \mathrm{W}$, et al. Synergistic effect of magnetic nanoparticles of $\mathrm{Fe} 3 \mathrm{O} 4$ with gambogic acid on apoptosis of $\mathrm{K} 562$ leukemia cells. Int J Nanomed. 2009;4:251-259. doi:10.2147/IJN. S7932

104. Fang LH, Chen BA, Liu SL, et al. Synergistic effect of a combination of nanoparticulate $\mathrm{Fe} 3 \mathrm{O} 4$ and gambogic acid on phosphatidylinositol 3-kinase/Akt/Bad pathway of LOVO cells. Int J Nanomed. 2012;7:4109-4118.

105. Wang WW, Li XY, Wang ZH, et al. A novel "mosaic-type" nanoparticle for selective drug release targeting hypoxic cancer cells. Nanoscale. 2019;11(5):2211-2222. doi:10.1039/C8NR06452K

106. Zhang Z, Qian HQ, Huang J, et al. Anti-EGFR-iRGD recombinant protein modified biomimetic nanoparticles loaded with gambogic acid to enhance targeting and antitumor ability in colorectal cancer treatment. Int $J$ Nanomed. 2018;13:4961-4975. doi:10.2147/IJN.S170148

107. Zhang DH, Zou ZY, Ren W, et al. Gambogic acid-loaded PEGPCL nanoparticles act as an effective antitumor agent against gastric cancer. Pharm Dev Technol. 2018;23(1):33-40. doi:10.1080/10837450.2017.1295068

108. Zhang Z, Qian HQ, Yang M, et al. Gambogic acid-loaded biomimetic nanoparticles in colorectal cancer treatment. Int J Nanomed. 2017;12:1593-1605. doi:10.2147/IJN.S127256

109. Wang SP, Shao M, Zhong ZF, et al. Co-delivery of gambogic acid and TRAIL plasmid by hyaluronic acid grafted PEI-PLGA nanoparticles for the treatment of triple negative breast cancer. Drug Deliv. 2017;24(1):1791-1800. doi:10.1080/10717544.2017.1406558

110. He MY, Ro LL, Liu J, Chu -C-C. Folate-decorated arginine-based poly(ester urea urethane) nanoparticles as carriers for gambogic acid and effect on cancer cells. J Biomed Mater Res A. 2017;105 (2):475-490. doi:10.1002/jbm.a.35924

111. Li R, He Y, Zhang S, Qin J, Wang J. Cell membrane-based nanoparticles: a new biomimetic platform for tumor diagnosis and treatment. Acta Pharm Sin B. 2018;8(1):14-22. doi:10.1016/ j.apsb.2017.11.009

112. Zhang Y, Yang ZJ, Tan XY, Tang X, Yang ZX. Development of a more efficient albumin-based delivery system for gambogic acid with low toxicity for lung cancer therapy. Aaps Pharmscitech. 2017;18(6):1987-1997. doi:10.1208/s12249-016-0670-4

113. Fang XB, Xu YQ, Wang SP, Wan JB, He CW, Chen MW. Pluronic F68-linoleic acid nano-spheres mediated delivery of gambogic acid for cancer therapy. Aaps Pharmscitech. 2017;18(1):147-155.

114. Yang $\mathrm{K}, \mathrm{Xu} \mathrm{H}$, Cheng L, Sun C, Wang J, Liu Z. In vitro and in vivo near-infrared photothermal therapy of cancer using polypyrrole organic nanoparticles. Adv Mater. 2012;24 (41):5586-5592. doi:10.1002/adma.201202625

115. Yang Y, Zhu WJ, Dong ZL, et al. 1D coordination polymer nanofibers for low-temperature photothermal therapy. Adv Mater. 2017;29:40.

116. Haine AT, Niidome T. Gold nanorods as nanodevices for bioimaging, photothermal therapeutics, and drug delivery. Chem Pharm Bull (Tokyo). 2017;65(7):625-628. doi:10.1248/cpb.c17-00102

117. Wan H-Y, Chen J-L, Yu X-Y, Zhu X-M. Titania-coated gold nanorods as an effective carrier for gambogic acid. RSC $A d v$. 2017;7(78):49518-49525. doi:10.1039/C7RA08560E
118. Ji Y, Shan S, He MY, Chu -C-C. Inclusion complex from cyclodextrin-grafted hyaluronic acid and pseudo protein as biodegradable nano-delivery vehicle for gambogic acid. Acta Biomater. 2017;62:234-245. doi:10.1016/j.actbio.2017.08.036

119. Zhan Q, Tang M. Research advances on apoptosis caused by quantum dots. Biol Trace Elem Res. 2014;161(1):3-12. doi:10.1007/s12011-014-0068-7

120. Xu PP, Li JY, Shi LX, Selke M, Chen BA, Wang XM. Synergetic effect of functional cadmium-tellurium quantum dots conjugated with gambogic acid for HepG2 cell-labeling and proliferation inhibition. Int J Nanomed. 2013;8:3729-3736. doi:10.2147/IJN. S51622

121. Kang YA, Lu L, Lan JS, et al. Redox-responsive polymeric micelles formed by conjugating gambogic acid with bioreducible poly(amido amine)s for the co-delivery of docetaxel and MMP-9 shRNA. Acta Biomater. 2018;68:137-153. doi:10.1016/j. actbio.2017.12.028

122. Huang WZ, Wang $\mathrm{X}$, Shi CY, et al. Fine-tuning vitamin E-containing telodendrimers for efficient delivery of gambogic acid in colon cancer treatment. Mol Pharmaceut. 2015;12 (4):1216-1229. doi:10.1021/acs.molpharmaceut.5b00051

123. Zhang Y, Tan XY, Ren TY, Jia C, Yang ZX, Sun H. Folatemodified carboxymethyl-chitosan/polyethylenimine/bovine serum albumin based complexes for tumor site-specific drug delivery. Carbohyd Polym. 2018;198:76-85. doi:10.1016/j. carbpol.2018.06.055

124. Yang Y, Cai HX, Yuan XY, et al. Efficient targeting drug delivery system for lewis lung carcinoma, leading to histomorphological abnormalities restoration, physiological and psychological statuses improvement, and metastasis inhibition. Mol Pharmaceut. 2018;15(5):2007-2016.

125. Tian FC, Dahmani FZ, Qiao JN, et al. A targeted nanoplatform co-delivering chemotherapeutic and antiangiogenic drugs as a tool to reverse multidrug resistance in breast cancer. Acta Biomater. 2018;75:398-412. doi:10.1016/j. actbio.2018.05.050

126. Xu YW, Wang CY, Ding YF, et al. Nanoparticles with optimal ratiometric co-delivery of docetaxel with gambogic acid for treatment of multidrug-resistant breast cancer. J Biomed Nanotechnol. 2016;12(9):1774-1781. doi:10.1166/jbn.2016.2282

127. Liu L, Qi X-J, Zhong Z-K, Zhang E-N. Nanomedicine-based combination of gambogic acid and retinoic acid chlorochalcone for enhanced anticancer efficacy in osteosarcoma. Biomed Pharmacother. 2016;83:79-84. doi:10.1016/j.biopha.2016.06.001

128. Dahmani FZ, Xiao Y, Zhang J, Yu Y, Zhou JP, Yao J. Multifunctional polymeric nanosystems for dual-targeted combinatorial chemo/antiangiogenesis therapy of tumors. Adv Healthc Mater. 2016;5(12):1447-1461. doi:10.1002/ adhm.201600169

129. Yao J, Li YK, Sun XJ, Dahmani FZ, Liu HP, Zhou JP. Nanoparticle delivery and combination therapy of gambogic acid and all-trans retinoic acid. Int $J$ Nanomed. 2014;9:3313-3324. doi:10.2147/IJN.S62793

130. Doddapaneni R, Patel K, Owaid IH, Singh M. Tumor neovasculature-targeted cationic PEGylated liposomes of gambogic acid for the treatment of triple-negative breast cancer. Drug Deliv. 2016;23(4):1232-1241. doi:10.3109/ 10717544.2015.1124472

131. Zhao W, You -C-C, Zhuang J-P, et al. Viability inhibition effect of gambogic acid combined with cisplatin on osteosarcoma cells via mitochondria-independent apoptotic pathway. Mol Cell Biochem. 2013;382(1-2):243-252. doi:10.1007/s11010-013-1740-5

132. Zou ZY, Xie L, Wei J, et al. Synergistic anti-proliferative effects of gambogic acid with docetaxel in gastrointestinal cancer cell lines. BMC Complement Altern Med. 2012;12(1):1-9. doi:10.1186/1472-6882-12-58 
133. Wang J, Liu W, Zhao Q, et al. Synergistic effect of 5 -fluorouracil with gambogic acid on BGC-823 human gastric carcinoma. Toxicology. 2009;256(1-2):135-140. doi:10.1016/j. tox.2008.11.014
134. Zhou Y, Wang RJ, Chen B, Sun D, Hu Y, Xu PP. Daunorubicin and gambogic acid coloaded cysteamine-CdTe quantum dots minimizing the multidrug resistance of lymphoma in vitro and in vivo. Int J Nanomed. 2016;11:5429-5442. doi:10.2147/IJN.S115037

\section{Publish your work in this journal}

The International Journal of Nanomedicine is an international, peerreviewed journal focusing on the application of nanotechnology in diagnostics, therapeutics, and drug delivery systems throughout the biomedical field. This journal is indexed on PubMed Central, MedLine, CAS, SciSearch ${ }^{\mathbb{B}}$, Current Contents ${ }^{\mathbb{B}} /$ Clinical Medicine, $^{2}$
Journal Citation Reports/Science Edition, EMBase, Scopus and the Elsevier Bibliographic databases. The manuscript management system is completely online and includes a very quick and fair peer-review system, which is all easy to use. Visit http://www.dovepress.com/ testimonials.php to read real quotes from published authors. 